\title{
Revisiting the Mannesmann takeover: how markets for corporate control emerge
}

\author{
Martin Höpner ${ }^{1}$, Gregory Jackson ${ }^{2}$ \\ ${ }^{1}$ Max-Planck-Institute for the Study of Societies, London, UK \\ ${ }^{2}$ King's College London, London, UK
}

\author{
MPIfG Journal Article \\ Martin Höpner, Gregory Jackson: Revisiting the Mannesmann Takeover : How Markets for Corporate Control Emerge. In: \\ European Management Review 3(3), $142-155$ (2006). Wiley-Blackwell \\ The original publication is available at the publisher's web site: $h$ ttp://dx.doi.org/10.1057/palgrave.emr.1500061 \\ The MPIfG Journal Articles series features articles by MPIfG researchers and visiting scholars published in peer-reviewed journals. \\ Max Planck Institute for the Study of Societies (MPIfG) Cologne | www.mpifg.de
}

Correspondence: King's College London, 150 Stamford Street, London SE1 9NH, UK.

Tel: + 44207848 4466;

E-mail: gregory.2.jackson@kcl.ac.uk

\begin{abstract}
Degrees of shareholder orientation among companies differ across countries as well as over time. Markets for corporate control are important elements of corporate governance regimes that affect such orientations. German corporate governance has often been described as a bank-oriented, blockholder, or stakeholder model where markets for corporate control play no significant role. This case study of the hostile takeover of Mannesmann AG by Vodafone in 2000 demonstrates how systemic changes during the 1990s have eroded past institutional barriers to takeovers. The emergence of a market for corporate control cannot be understood by looking at takeover regulation in isolation. Rather, takeover markets rely on a whole set of complementary institutions, social practices, and predominant interpretations, such as banking strategies, codetermination practices, company regulation, and business ideologies. A limited, but significant segment of German corporations are now subjected to a market for corporate control.

European Management Review (2006) 3, 142-155. doi:10.1057/palgrave.emr.1500061

Keywords: Corporate governance; market for corporate control; comparative institutional analysis; takeovers; Germany
\end{abstract}

A

longside markets for products, labor, and finance, the market for corporate control represent a distinct fourth type of capitalist market - thereby turning companies that combine capital and labor in the production of commodities into commodities themselves (Windolf, 1994). On the one hand, the market for corporate control is often seen as an important mechanism of corporate governance. Given the dispersed nature of corporate ownership, poorly performing firms may be purchased at a low price and inefficient management replaced (Manne, 1965). On the other, takeovers may also lead the transfer of wealth from stakeholders to shareholders and lead to net losses of efficiency or wealth due to 'breaches of trust' (Shleifer and Summers, 1988). In both cases, markets for corporate control have crucial consequences for the distribution of power over corporations.

Takeover activity varies across countries related to the institutional characteristics of different national business systems (O'Sullivan, 2000; Hall and Soskice, 2001; Rossi and Volpin, 2003; Schneper and Guillen, 2004; Goergen et al., 2005). While the market for corporate control has played little role in Continental Europe, the increasing mergers and acquisitions (M\&A) since the 1990s have also been associated with the emergence of hostile bids. Despite some past hostile transactions involving large blockholders
(Jenkinson and Ljungvist, 2001), Germany witnessed its first major hostile takeover battles at Hoesch, Thyssen, and Continental. But the takeover of Mannesmann by Vodafone between November 1999 and February 2000 represents a decisive watershed. The takeover was one of the largest deals in the world, and reflects the dramatic power of stock market capitalization in leveraging the takeover of the industrial giant Mannesmann (130,860 employees, 23 billion euros in turnover, 109 years old) by a newer and smaller rival Vodafone (29.465 employees, 13 billion euros in turnover, 15 years old).

This paper presents a case study of the Mannesmann takeover and revisits its significance for German corporate governance. Whereas German corporate governance institutions are argued to act as a strong barrier to hostile transactions, we emphasize that a number of incremental, but non-trivial changes made the Mannesmann deal possible. In analyzing the inter-related nature of these changes, we offer insights into the behavioral and institutional preconditions of markets for corporate control. We argue that these preconditions rely not only upon takeover regulation, but a set of interdependent practices, business ideologies and complementary institutions. The emergence of markets cannot be understood apart from their embeddedness, in particular, social foundations. 
Our argument relies upon an actor-centered perspective of institutions (Aguilera and Jackson, 2003; Crouch, 2005) that focuses attention on how actors are involved in the diffusion, adaptation, and contestation of new practices across different institutional contexts (Fiss and Zajac, 2004; Sanders and Tuschke, 2006). The emergence of takeover markets in Germany is not explained by the wholesale adoption of market-oriented or Anglo-Saxon business institutions, but the accumulation of incremental changes, strategic adjustments, and experiments at the boundaries of institutional constraints. Both institutional change and continuity help to explain why a takeover market has emerged, but retains its own distinctive characteristics (see also Jackson and Miyajima, 2006). The 'market' for corporate control reflects the intensified competition for the control of large companies, and competitive strategies oriented to stock prices to mediate that competition in Germany. While we do not see such change as leading to cross-national convergence, we conclude that this gradual emergence of a market for corporate control in Germany represents a major change of its post-war corporate governance institutions. The change points to the increasingly 'hybrid' character of German corporate governance, which draws on a selective mixture of both market and non-market or shareholder and stakeholder-oriented elements (Höpner, 2001; Jackson, 2003; Vitols, 2004; Buck and Shahrim, 2005).

The next section briefly reviews the economic and institutional factors influencing the development of markets for corporate control across countries. Next, we followup with a section that identifies the specific managerial and institutional features suppressing these markets in Germany. The subsequent section presents the Mannesmann case, showing how these factors failed to have deterrent effects. The penultimate section discusses the potential emergence of a market for corporate control in Germany. The last section draws some further implications of takeovers for German corporate governance.

\section{The market for corporate control}

M\&A are important aspects of corporate strategy and often arise in response to technological, economic, or institutional change. Where $M \& A$ develops into a market for corporate control, takeovers have strong implications for corporate governance. As Henry Manne (1965: 113) argued: 'The lower the stock price, relative to what it could be with more efficient management, the more attractive the takeover becomes to those who believe that they can manage the company more efficiently.' Particularly where owners are dispersed, lower share prices create incentives for outsiders to accumulate control rights, replace management, and restructure the firm. An institutionalized threat of hostile takeovers exerts market discipline on potential target firms to raise returns. Meanwhile, hostile takeovers are also thought to lead to 'breaches of trust' among corporate stakeholders (Shleifer and Summers, 1988) and raise questions about the potential consequences for employees (e.g., see Conyon et al., 2001, 2004; Aguilera and Dencker, 2004).

Consequently, the presence or absence of hostile takeovers reflects a central distinction among national systems of corporate governance (Kester, 1990; Baums, 1993; Aguilera and Jackson, 2003). For example, bank monitoring may effectively substitute for the market for corporate control. Meanwhile, the absence of takeovers means that a greater proportion of corporate wealth goes to employees and reinvestment in corporate growth in Germany than in Britain (De Jong, 1996). Firms who are free from the threat of takeovers retain a wider range of strategic options: pursuing higher market share, spending more on capital and $\mathrm{R} \& \mathrm{D}$ investment; specializing on market segments offering lower returns but large size and relatively low risk; and absorbing higher labor costs to avoid layoffs during downturns and protect employee morale and firm-specific human capital. These strategies are associated comparative institutional advantages for certain industrial sectors (Hall and Soskice, 2001).

Cross-national differences in the level and type of takeover activity relate to a number of institutional and historical factors that affect the power differentials among various corporate stakeholders (see Rossi and Volpin, 2003; Schneper and Guillen, 2004; Pagano and Volpin, 2005). First, M\&A activity is higher where minority shareholders enjoy strong legal protection through shareholder rights or stringent financial accounting standards. In terms of hostile bids, an important aspect concerns takeover rules, such as mandatory bid rules, board neutrality, and the potential for takeover defences, such as poison pills. Second, high ownership concentration and dense inter-firm networks act as a barrier against hostile takeovers, since concentrated owners must be willing to sell. Related to this, relationshiporiented banks often play a strategic role in defending companies from hostile bids. Third, both friendly and hostile M\&A is higher in countries where employment protection law (e.g. rights regarding dismissal) or employee participation rights are weak. Finally, M\&A activity may also be legitimated to a greater or lesser degree depending upon the educational backgrounds and ideologies of top managers (Fligstein, 1990). All of these factors are important for the German case, although any one could theoretically be a sufficient condition for preventing an active takeover market.

Recent institutional analysis of takeover markets often compares a broad cross-section of OECD countries in a single point in time. By contrast, this paper adopts actor-centered perspective that explores how institutional constraints and opportunities evolve within countries as a result of varieties in firms' strategic behavior (Sako and Jackson, 2006) and the re-interpretation of institutions (Streeck and Thelen, 2005). The next section will examine the institutional barriers to hostile takeovers in Germany showing that, despite important legal reforms and other changes, many of these barriers remained at the time of the Mannesmann deal. The case study of Mannesmann will then be used to explore how different actors coped with those institutional constrains and made the hostile takeover of Mannesmann possible.

\section{The changing role of takeovers in Germany}

Until the early 1990s, Germany had relatively low merger activity compared to other European countries. During the 1970 s, an average of 373 mergers were reported to the Federal Cartel Office compared to an annual average of 827 
during the 1980s. A large wave of mergers with East German firms followed German unification, and continued throughout the 1990s due to the integration and liberalization of European markets such as banking, utilities or business services, as well as technology boom in internet and telecommunications (Martynova and Renneboog, 2006). During 1991-1997, Germany averaged 1479 deals annually worth $1.4 \%$ of GDP (Jackson and Miyajima, 2006). During 1998-2005, this level increased to 1607 deals annually with a value equivalent to $7.5 \%$ of GDP, threequarters of which was cross-border. ${ }^{1}$ Despite this large historical increase, the number and relative value of M\&A in Germany still remains behind the UK. However, other indicators suggest a similar level of market exposure $11 \%$ of all listed firms were targeted in M\&A transactions (both mergers and stake acquisitions) in Germany during 1998-2005, compared to just $9 \%$ in the UK and $10 \%$ in the US.

Nonetheless, Germany is normally characterized as having corporate governance institutions that act as barriers to hostile takeovers: concentrated ownership, bank monitoring, employee codetermination, weak transparency and shareholder protection, and insider management focused on promoting the long-term interests of the firm (Baums, 1993; Schmidt, 1997: 128-130). Next, we explore each in turn.

\section{Ownership structure}

The willingness of owners to sell their shares to hostile bidders differs with respect to the type of shareholder and the concentration of their stakes. Table 1 shows the changes in ownership of listed firms between 1995 and 2004. The share of ownership by 'stable' strategic owners such as nonfinancial firms, banks, insurance firms, and government decreased from $66.8 \%$ in 1995 to $57.2 \%$ in 2000 and $55.7 \%$ in 2004. The biggest negative shift was among non-financial firms. The share of ownership by more 'financially oriented' investors such as investment firms, individuals, and foreigners increased from $33.2 \%$ in 1995 to $43.4 \%$ in 2000 and $44.3 \%$ in 2004 . The largest increase here has been among investment firms and foreign investors, particularly institutional investors such as UK and US pension funds. These changes have dramatically decreased the density of networks among the largest German companies (Höpner and Krempel, 2004). A new tax policy in 2002 has facilitated the unwinding of intercorporate and bank holdings by eliminating capital gains tax on the sale of corporate shares.
In terms of ownership concentration, we also look further at the ownership of the 100 largest firms between 1978 and 2002 (see Table 2). Most German firms are owned by a blockholder such as a family, a firm, the government, or increasingly also foreign blockholders. Actual control rights of these blockholders are further reinforced by pyramid schemes (Franks and Mayer, 2001). While blockholders may sometimes sell their stakes to outside bidders or engage in hostile bids, the presence of a large blockholder is likely to preclude a hostile bid from a third party. The likelihood of hostile bids depends on dispersed ownership. However, the number of firms with dispersed ownership has not increased over this time period. Although only 22 of the 100 largest (listed and unlisted) German companies had a majority of dispersed ownership in 2002, its significance must not be underestimated. The average company among the 100 largest has $20.9 \%$ dispersed ownership, but this figure increases to $52 \%$ among listed firms. Moreover, the largest company is 31 times larger than company number 100 , and size and dispersed ownership are highly correlated (Pearson's $r=0.51, P=0.000$ ). Dispersed ownership represents $39.7 \%$ of the value added of the 100 largest in weighted terms and includes many flagships of German business, such as DaimlerChrysler, Siemens, Bayer, BASF, Deutsche Bank, Allianz, and Deutsche Lufthansa.

\section{Influence of banks}

Even among firms with fragmented ownership, banks are often thought to play a defensive role. Many major private banks had little interest in promoting hostile bids, since banks are also widely held corporations whose

Table 1 Percentage of share ownership in Germany by sector, 1995-2004

\begin{tabular}{lrrr}
\hline & 1995 & 2000 & 2004 \\
\hline Non-financial firms & 45.8 & 36.9 & 33.8 \\
Banks & 12.9 & 11.5 & 9.9 \\
Insurance firms & 6.3 & 8.2 & 11.1 \\
Government & 1.8 & 0.6 & 0.9 \\
Investment firms and other & 6.2 & 14.4 & 13.4 \\
financial institutions & & & \\
Individuals & 18.8 & 16.5 & 14.1 \\
Foreign & 8.2 & 12.5 & 16.8 \\
\hline
\end{tabular}

Source: Deutsche Bundesbank, Gesamtwirtschaftliche Finanzierungsrechnung, 1991 bis 2004.

Table 2 Ownership structure among the largest 100 German corporations, in percent, 1978-2002

\begin{tabular}{lcrrrr}
\hline & 1978 & 1988 & 1998 & 2000 & 2002 \\
\hline Majority held by single individual, family, or foundation & 18 & 21 & 18 & 16 & 19 \\
Majority held by foreign company & 20 & 16 & 17 & 23 & 25 \\
Majority held by government & 11 & 13 & 13 & 12 & 11 \\
Other majorities & 4 & 4 & 9 & 22 & 20 \\
Dispersed ownership $^{\mathrm{a}}$ & 22 & 28 & 22 \\
No clear majorities & 25 & 18 & 21 & 18 \\
\hline
\end{tabular}

${ }^{a}$ Over $50 \%$ of ownership is fragmented (possible minority blockholders).

Sources: Hauptgutachten Monopolkommission, various years. 
shares are voted through proxies of other banks (Baums, 1993). Banks exert influence through direct ownership, Supervisory Board seats, and casting a high proportion of proxy votes that can be used to support management by amending corporate statutes with anti-takeover provisions. In the early 1990s, banks chaired $40 \%$ of Supervisory Board among the 40 largest listed industrial companies (Höpner, 2003: 138). In sum, banks were willing to organize defensive measures against hostile takeovers and enjoyed numerous channels to collect information and influence other companies not to support hostile takeovers or even acquire defensive blocks.

German banks have shifted strategy overtly and dramatically toward UK or US-style investment banking (Hackethal et al., 2005), and even supporting hostile bids. The takeover of Hoesch by Krupp in 1991 was a hallmark case. Krupp was informally supported in its takeover attempt by its house bank WestLB, which accumulated a $12 \%$ stake in Hoesch. Likewise, Deutsche Bank was supposedly informed and supported the Krupp bid despite its role as Hoesch's house bank and its seat chairing Hoesch's Supervisory Board. The growing dilemmas facing banks as they shift from traditional 'house bank' relations toward investment banking services are further illustrated by the battle for control over Thyssen in 1997. Deutsche Bank was active in advising Krupp in the unfriendly takeover bid, while its management held a seat on Thyssen's Supervisory Board. The implied conflicts of interest received sharp public criticism and protest from the industrial union IG Metall. As a result of such conflicts, banks are generally moving to reduce their monitoring role. In March 2001, Deutsche Bank announced that it will no longer hold the chair on the boards of non-financial corporations (Deutsche Bank, 2001).

\section{Codetermination}

In Germany, employee representatives on the Supervisory Board act as a barrier to hostile transactions by lessening the direct influence of shareholders and being likely to support takeover defenses. Codetermination can be decisive if the shareholder side of the Supervisory Board is divided among competing factions. This is particularly true for companies with 'parity' codetermination under the Codetermination Act of 1951, since Supervisory Boards are chaired by a 'neutral' person with a tie-breaking vote. More broadly, codetermination and strong employment law helps to protect employee interests and reduce the capacity of hostile raiders to engage in ex post redistribution of wealth following takeovers through collective dismissals. In terms of regulation, codetermination remained unaltered in the period we observe. However, as we will discuss later, whether or not codetermination acts as a 'poison pill' for hostile takeovers depends strongly on the strategic orientation of works councils and trade unionists. In this regard, codetermination has displayed a trend toward a greater productivity and consensus orientation during the 1990s (Höpner, 2003; Vitols, 2004).

\section{Accounting and disclosure issues}

German accounting and disclosure rules are often considered to lack transparency. Substantial discretion exists in the creation of hidden reserves and the valuation of assets. Traditionally, German accounting has stressed very conservative prudence rules (Vorsichtsprinzip), creditor protection and long-term business conservatism. Both international standards (IAS) and US rules (GAAP) are more investor oriented: aiming for greater disclosure, valuation based on current market prices and stricter definition of profits. While the large hidden reserves possible under German accounting rules might make companies attractive targets, it also makes takeovers more risky since liabilities remain undisclosed and true levels of profit may be hard to gauge. In addition, the strict capital protection rules prohibit the use of certain financial techniques during takeovers, particularly using the assets of target firms during levered buyouts as in the United States. International accounting has diffused quickly among large German firms. In 1994, Daimler-Benz was the first German company that published US-GAAP balance sheets. By 2002, 43 of the 100 largest German companies published balance sheets in accordance with US-GAAP or IAS (now: IFRS) accounting rules. Among them are 21 of the 22 companies with more than $50 \%$ of dispersed ownership (data: Monopolkommission).

Another issue concerns the disclosure of ownership stakes. Lack of disclosure may give bidders the advantage of being able to accumulate quite large stakes without being detected. However, lack of transparency might also discourage potential bidders, since they cannot estimate the power of minority blockholders acting as white knights in defending the target company. As argued above, lack of disclosure makes takeover battles more uncertain and risky. Other things being equal, such rules likely lower the level of takeover activity. Until recently, disclosure was required in Germany only for stakes exceeding $25 \%$ compared with thresholds of $5 \%$ in the United States and $3 \%$ in Britain. However, German regulations were changed in 1998 to require reporting of stakes at the thresholds of $5,10,25,50$, or $75 \%$.

\section{Company law}

Corporate law influences takeovers in several ways. Germany historically had low levels of protection for minority shareholders, which discourages takeovers (La Porta et al., 1998). Voting rights departing from a 'one share, one vote' principle were thus an important takeover defense in Germany. In 1991, 6.6\% of listed firms had non-voting shares, $3.8 \%$ had caps on voting rights, and 4.5\% limited share transferability (Jenkinson and Ljungvist, 2001). Voting rights caps played an important role in takeover battles such as Continental arrangements and Feldmühle Nobel. These voting rights were largely eliminated or greatly restricted by reforms in 1998 (KonTraG law). Today, 97\% of large German firms have one share-one vote, which exceeds the $88 \%$ of UK firms (Deminor Rating, 2005). Other legal reforms liberalized the use of corporate equity to allow M\&A transactions through share swaps. 
Company law also influences changes in control. For example, Supervisory Boards members on the shareholder bench can be difficult to dismiss before their term expires even through a shareholder vote. The law of groups of companies (Konzernrecht) also introduces special control rights associated with company groups in order to protect minority shareholders and creditors of subsidiary companies. When companies are acquired, German law requires the conclusion of a 'conglomerate contract' (Beherrschungsvertrag) in order to protect the interests of the subordinate company, which requires both a $75 \%$ super-majority shareholder resolution and compensation for affected parties.

\section{Defensive actions}

Given the historically low level of hostile bids, overt takeover defenses have played only a marginal role in Germany. A voluntary takeover code was introduced in 1995 , but only 540 of 933 listed companies and 79 of the DAX-100 corporations complied in 1999 (Bundesministerium der Finanzen, 2000). Following the Mannesmann case, a renewed discussion emerged over takeover law. Meanwhile, a draft EU takeover directive was proposed but deadlocked in the European Parliament (Callaghan and Höpner, 2005). A central issue was the requirement for board 'neutrality' during hostile bids. Germany later passed a Takeover Act in 2002 drawing on a previous draft law, but replacing board neutrality with the option for defensive actions given prior shareholder approval. Specifically, the shareholders' meeting can empower management to take defensive action for an 18 -month period with a $75 \%$ majority vote. When passed in 2004, the European Takeover Directive was based broadly on principles of the UK Takeover Code (Goergen et al., 2005), but allows Germany or other countries to optout on some provisions with regard to takeover defenses.

While much has been made out of opt-out provisions, these legal changes have in effective drastically restricted the scope for defensive actions. For example, US-style 'poison pills' found under Delaware law are impossible in Germany, since issuing discounted shares is incompatible with the equal treatment of shareholders under the $\mathrm{EU}$ Takeover Directive and the preemptive rights for existing shareholders under German law. The board may attempt to issue authorized share capital (202-206 AktG) to existing shareholders up to a maximum $50 \%$ of capital. However, it remains highly disputed among legal scholars as to what extent this could be used as a realistic takeover defense. And while a three-quarters majority of shareholders may pass a reserve authorization (Art 33(2) WpÜG) that allows managers to frustrate a bid, additional approval is required from the Supervisory Board upon implementation. Legal scholars have speculated about what actions German boards might take if authorized by the shareholders meeting to defend the company, such as selling off pieces of the firm to prevent acquisition (Gordon, 2003). However, court decisions (the Holzmüller doctrine) have led to requiring shareholder approval for substantial $(>80 \%)$ acquisitions or asset disposals. Given these restrictions, the board must be increasingly neutral and defensive strategies are largely limited to share buy-backs, engaging in alternative acquisitions, and searching for a white knight.

\section{Managerial ideologies and corporate culture}

German management was traditionally strongly oriented toward production and engineering. Financial specialists rarely became the speaker of the Management Board. German management was characterized by dominance of internal careers and, inversely, underdeveloped external labor markets for managers. Poensgen (1982: 17) has shown that in the 1960 s and 1970 s, only around $50 \%$ of top managers of large and middle-sized German firms had a university degree; therefore, historically, vocational training was as important for German management as university degrees were. From those with a university degree, $60 \%$ were natural scientists and engineers, compared to $30 \%$ of economists and $10 \%$ of lawyers. German managers emphasized structural and operational aspects of management (Guillén, 1994) and stressed the importance of the organizational compatibility of firms during mergers, rather than the financial logic.

Likewise, a strong consensus orientation of managers may work against both initiating takeover bids and undertaking radical restructuring after takeovers. Boards have a norm of consensus decision-making based on the legal position of the Management Board as a collegial entity with collective responsibility for decisions and often did not even elect a spokesperson until the late 1980s. More broadly, Germany has a relatively weak 'equity culture.' Stock market activity is viewed as inherently risky and speculative. The US experience with hostile takeovers, bustups, corporate downsizing, and shareholder value was widely considered ruthless 'Wild West' tactics in Germany. Thus, public acceptance of takeover battles has been low and arguments for the efficiency of hostile takeovers viewed with skepticism. During the 1990s, shareholder oriented management concepts gained ground in German corporations, and the share of CEOs with financial backgrounds rose significantly (Höpner, 2003: 123-133).

\section{The case of Mannesmann}

The Mannesmann case was unprecedented in post-war Germany as a successful hostile takeover bid made on the open market. Mannesmann was founded in 1890 to produce seamless tubes. Deutsche Bank was influential in wresting control of the ailing firm away from its founders in 1893. The company diversified into coal and steel in the early 20th Century, and into machine tools and automotive products in the 1970s and 1980s. Further change began in the 1990s following the liberalization of the German telecommunications market. Mannesmann set up a new mobile phone network, D2, and two-thirds of total investment went into telecommunications to make it the largest business segment. Mannesmann also established itself throughout Europe by acquisitions of foreign companies.

After becoming chair of the Management Board in May 1999, Klaus Esser announced the spin-off of industrial businesses and a future specialization on telecommunications in September 1999. Esser is representative of new managerial elites in Germany that strengthened their prestige and promotion prospects during the 1990s. He joined Mannesmann in 1977. Just like his precursor Joachim Funk (CEO between 1994 and 1998), he became 
CEO after having led the finance department at Mannesmann. However, unlike Funk, Esser had deep exposure to Anglo-American business practices. After receiving his German law diploma in 1974, he was awarded a business degree from the Massachusetts Institute of Technology (MIT) and worked as a lawyer in New York in 1976 to 1977. As CEO of Mannesmann, Esser continued the restructuring of Mannesmann but unlike Funk, he also began adjusting the business to Anglo-American standards of investor orientation. His strategy aimed at giving investors a stock with a clear financial logic, since telecommunications was valued more highly than the traditional machine tools and automotive businesses. The IPOs of the industrial businesses were planned for the year 2000 .

\section{Ownership, the stock market, and shareholder value}

Mannesmann's vulnerability to a hostile bid reflects its unusually dispersed ownership structure. Table 3 shows the shareholders in Mannesmann at the time of the takeover bid. After a share swap acquisition of Orange PLC, its previous owner, Hong Kong conglomerate Hutchison Whampoa, held the only large block stake in Mannesmann. Their group manager, Canning Fok, also joined the Supervisory Board of Mannesmann. While initially supporting Mannesmann, he later played a crucial role in pushing Esser to accept an improved takeover offer. As a result, Hutchinson generated nearly 21 billion euro from the deal and effectively swapped Orange, its $2 \mathrm{G}$ telecoms operator, for cash to pursue its expensive $3 \mathrm{G}$ strategy.

The remaining shareholders were institutional investors, such as pension funds or other asset management companies, with diversified portfolios and relatively small stakes. These shareholders largely pursue financial interests of increasing their portfolio returns, and thus are largely concerned about share price rather than long-term strategic considerations. Even if some funds wanted to reject the bid, their stakes were also too dispersed to mount coordinated opposition to the bid - the top ten shareholders controlled just $25.7 \%$ in total. While some German funds were thought to be loyal to Mannesmann, foreign investors held over $60 \%$ of shares, including $40 \%$ held by US and British investors alone. Despite speculation about shares owned by employees and AFL-CIO pension funds, only $15 \%$ of Mannesmann shares was estimated to be in loyal hands at the time of the takeover bid.

While Mannesmann had excellent stock market performance, it remained undervalued compared to its British rival Vodafone. Mannesmann shares increased nearly ninefold from 34 euros in 1996 to 300 euros in February 2000, outperforming the DAX-30 index. During the same period, Vodafone also had a seven-fold increase in its share price from 49 to 343 pounds. In 1992, Mannesmann's price-book ratio (PBR) was just 1.4, but grew over the 1990 s to 10.2 in 1999. Meanwhile, Vodafone had a PBR of 7.7, which grew to some 125.5 in 1999. Both telecommunications companies were valued at astronomically high levels, reflected in Mannesmann's price-earnings ratio (PER) of 56.1 and Vodafone's PER of 54.4 in September 1999. However, Table 4 shows that Mannesmann and Vodafone reflected very different patterns of financial valuation. Mannesmann was much larger than Vodafone in terms of sales and employment. But Vodafone was more profitable in broad terms, due to its focus on the high return market segment of mobile phones. Consequently, Vodafone achieved much higher stock market valuation relative to its underlying level of sales and employment and thus had a slightly higher market capitalization despite its much smaller base of 'real' economic activity. Thus, the stock market was an important source of power giving Vodafone leverage over Mannesmann, particularly since the transaction was performed through a share swap. It is an interesting further question whether such different patterns of valuation reflect an institutional difference between the British and German economy.

Table 3 Largest shareholders at Mannesmann AG, 1999

\begin{tabular}{llr}
\hline Shareholder & Country/number & Percent \\
\hline Hutchison Whampoa & Hongkong & 10.2 \\
Capital Research \& Management & US & 2.8 \\
Schroder Investment Management & UK & 2.1 \\
Janus Capital Corp. & US & UK/Hongkong \\
Templeton Investment Management & Germany \\
Deka Deutsche Kapitalgesellschaft & Germany/US/UK \\
Deutsche Asset Management & US \\
Alliance Capital Management & US \\
American Express Asset Management & Germany \\
DWS Deutsche Gesellschaft für Wertpapiersparen & \\
& 1.8 \\
Cumulative total, stakes of 1\% or more & 27 shareholders \\
Cumulative total, stakes of $0.5 \%$ or more & 63 shareholders \\
Cumulative total, stakes of $0.1 \%$ or more & \\
Subtotal Germany & 1.8 \\
Subtotal UK, US & 1.6 \\
\hline
\end{tabular}

${ }^{a}$ Total in parentheses shown excluding Hutchison Whampoa.

Source: Wirtschaftswoche, January 20, 2000, data provided by Thomson Financial Securities Data. 
Table 4 A comparison of Mannesmann AG and Vodafone airtouch PLC, March 2000

\begin{tabular}{|c|c|c|}
\hline & Mannesmann & Vodafone \\
\hline \multicolumn{3}{|l|}{ Sales, employment, and profits } \\
\hline Turnover (mill. euros) & 23,265 & 13,069 \\
\hline Employees & 130,860 & 29,465 \\
\hline $\begin{array}{l}\text { Return on sales } \\
\text { (EBITDA to sales) }\end{array}$ & $18.45 \%$ & $40.25 \%$ \\
\hline \multicolumn{3}{|l|}{ Market valuation } \\
\hline Market value (mill. euros) & 119,572 & 149,400 \\
\hline $\begin{array}{l}\text { Ratio of market value } \\
\text { to turnover }\end{array}$ & 5.14 & 11.40 \\
\hline $\begin{array}{l}\text { Market value per employee } \\
\text { (mill. euros) }\end{array}$ & 0.91 & 5.07 \\
\hline
\end{tabular}

Note: Data are for the year ending in March 2000.

Source: Annual reports, 1999 and 2000.

Mannesmann remained less capital market oriented than would be predicted on the basis of indicators such as size, international orientation, level of diversification, and ownership structure (Höpner, 2001). While receiving good ratings for investor relations, Mannesmann had not yet adopted IAS or US-GAAP standards, nor listed on the New York Stock Exchange. Managerial compensation was not tightly coupled to share prices, and few shareholder valueoriented performance criteria had been implemented on the operational level. However, Esser's tenure marked a refocusing of the business and efforts at increased information for shareholders.

\section{The takeover bid and defensive strategy}

Vodafone and Mannesmann were alliance partners up until Fall 1999. Vodafone focused exclusively on mobile networks and held a very large number of minority stakes in 13 European and 10 non-European countries. Mannesmann and Vodafone participated jointly in E-Plus, and Vodafone controlled a $34.8 \%$ stake in Mannesmann Mobilfunk. Meanwhile, Mannesmann pursued a broader two-fold strategy of both mobile and fixed line communications.

In October 1999, Mannesmann made a takeover bid for Orange (UK) worth some 30 billion euros. This move threatened Vodafone's home market, and on November 14, Vodafone's Chris Gent traveled to Germany to make a friendly merger offer through a swap of 43.7 Vodafone shares for one Mannesmann share. ${ }^{2}$ After Esser refused, the Mannesmann share prices surged due to further speculation. Chris Gent launched a public bid on November 23 a pure swap of 53.7 Vodafone shares for one Mannesmann share, thus bettering the previous 100 billion euro offer to 124 billion euro. Vodafone's published offer cited the economies of scale through activities in 25 countries that would reach 42.4 million customers - thereby arguing for a greater market value of a combined company. Gent did acknowledge the fact that hostile takeovers had generally been viewed as morally bad in Germany. But he attempted to portray Vodafone in the role of the victim rather than aggressor. The takeover of Orange had betrayed
Mannesmann's role as a strategic ally. Gent stressed the industrial rather than financial motives for the takeover. $\mathrm{He}$ made assurances that no closures or redundancies were planned. Gent described Vodafone as being appropriate, honest, and playing by the rules. Vodafone would abide by Germany's voluntary takeover code. The German code was notably more bidder-friendly than the British code, since it allows subsequent improvements to the offer and permits pure share swaps with no cash component.

Before 1998, Mannesmann management had not generally considered the threat of a hostile takeover bid. A most remarkable aspect of the defensive strategy was that Esser never questioned the general legitimacy of hostile takeovers, nor did he appeal to a defense of Germany's stakeholder model. In the published statements, Mannesmann made no reference to the dangers of job losses or the expected erosion of Supervisory Board codetermination. During the hostile attacks on Thyssen by Krupp in 1997 and Continental by Pirelli in 1991, defensive rhetoric was full of such references. Rather, Esser portrayed Vodafone's offer as a value-destroying measure for shareholders - an unusual and surprising rhetoric in the light of traditional German economic culture. With the support of the Supervisory Board that included both German banks and union representatives, the takeover defense stressed Mannesmann's business strategy of integrating mobile communication networks, fixed-line networks, and the Internet as a means to increase customer loyalty, raise the value of sales per customer, and lower customer turnover rates. This integrated strategy stood in sharp contrast to Vodafone's exclusive focus on mobile communication. Esser also argued that a successful takeover would remove Mannesmann from the German stock index (DAX) and Euro-Stoxx indices, forcing the divestment of index funds and depressing share prices.

By the end of January 2000, the defense shifted toward technical and procedural questions stemming from German company law and the takeover code. Before approving the merger, the European Union competition regime would require divestment of Orange in order to prevent a monopolistic market position for Vodafone in Britain. Under German law, divestment of Orange might require a 'control contract' between Vodafone and Mannesmann, as well as a cash payment to any minority shareholders not exchanging their shares. A control contract also requires a $75 \%$ majority, thus raising the quorum for control. The lengthy alternative would be to elect a new Supervisory Board with a simple majority, elect a new Management Board to sell Orange, and then complete the final merger. Vodafone contested these claims and argued that a simple majority was sufficient to complete the merger, while legal experts remained divided over the issue. Another legal uncertainty was that the tax on speculative stock trading (profits on stock held for less than one year) might require a de facto doubling of the time limit, since 12 months would have to elapse after the stock swap before shareholders could take their profits without tax.

In the end, Esser appealed to the fact that Mannesmann's share price increase made a swap unattractive as the price of Mannesmann shares climbed before the deadline of the share swap. The IPO of the automobile and engineering divisions was brought forward to capture such effects, and 
an announcement that the company was seeking a separate listing for Internet activities was made in January.

\section{Banks and investment bankers}

Banks played no defensive role for Mannesmann. Although no banks held a large stake in Mannesmann, Deutsche Bank manager Josef Ackermann was a Supervisory Board member. The lack of involvement can be explained by the dramatic reorientation of German banks toward investment banking. In the 1991 bid for Continental by Pirelli, the Deutsche Bank mobilized a defensive ownership block, but only after protracted internal debate. In the 1997 Thyssen-Krupp deal, Deutsche Bank again had a conflicting position in advising Krupp in the bid and holding a seat in the target company Thyssen. Klaus Breuer (Deutsche Bank, Management Board chair) made this revealing quote with reference to the Krupp-Thyssen takeover in 1997: 'I very much hope that a first large case [takeover] will set an example within our financial culture' (Spiegel 13/1997: 94). These cases led to severe public criticism over the role of banks. As investment banking has emerged as a dominant strategy in the 1990s, banks could no longer act as both an investment bank according the rules of the international marketplace and simultaneously support the old style of relationship banking defending management against takeovers. Thus, the Deutsche Bank sent a signal that it would no longer defend 'their' German firms in international takeovers.

Meanwhile, investment banks played key roles as consultants on both sides. M\&A consulting is highly concentrated among the 10 most important and predominately Anglo-American investment banks. In 1998, Mannesmann allegedly hired Morgan Stanley and Deutsche Bank to develop defensive strategies to hostile bids. During the takeover battle, Mannesmann was advised by Morgan Stanley, Merrill Lynch, and JP Morgan. Meanwhile, Vodafone worked closely with Goldman Sachs and Warburg Dillon Read. Klaus Esser had demanded that Goldman Sachs should stop advising Vodafone because Goldman Sachs had advised Orange in its friendly merger with Mannesmann. However, Mannesmann's petition to the High Court in London was refused on the grounds that the information involved was not confidential enough to warrant it. Similarly, Morgan Stanley had advised Airtouch during its takeover by Vodafone, but was now advising Mannesmann.

\section{Works councils, employee share ownership, and unions}

Codetermination was also discussed above as an institutional element that might act as a poison pill to prevent hostile takeovers. Mannesmann was one of the corporations with the most extensive parity model of codetermination (Montanmitbestimmung). Here, the Supervisory Board chair is a 'neutral' person agreed upon by both shareholder and labor. And a labor director is appointed to the Management Board with the consent of the labor representatives. For over 20 years, Mannesmann sought to flee the jurisdiction of these laws (Spieker and Strohauer, 1982). As steel accounted for less than $50 \%$ of turnover, Mannesmann legally contested the application of the law and caused considerable conflict with IG Metall in 1980/
1981. This conflict resulted in a special law that extended the old rules for another six years and in 1988 in a revision lowering the threshold for the coal, iron, and steel sector from $50 \%$ to just $20 \%$ of sales. In May 1999, the Constitutional Court ruled these special laws unconstitutional. While freed form legal obligation, the past labor director elected, Siegmar Sattler, remained on the Management Board throughout the takeover battle. Codetermination is particularly strong in the traditional areas such as steel, but less developed in the area of telecommunications, which has lower rates of union organization.

Much discussion took place about the compatibility of capital market-oriented management and codetermination in Germany. It is interesting to note that many of the measures to reorient Mannesmann toward shareholder value were welcomed by IG Metall and the works councils. Labor representatives praised growing corporate transparency and benefited from more information disclosure. More surprising is that the planned breakup of Mannesmann into legally separate corporations was not only welcomed but also actively promoted by labor. The explanation lies in the heterogeneous structure of the company. Telecommunications had become the focal segment and attracted a growing proportion of funds for investment. A trade union official described the situation as follows: 'The development of telecommunications was gradually becoming dangerous for the other divisions. While billions were being spent on the acquisition of Orange, we had to fight for every hammer in the classical businesses' (interview). The return on investment for the traditional businesses was lower, but the risks were also much lower too. Organized labor supported their separation to allow these businesses to continue an 'undisturbed' development. Conversely, the telecommunications business was arguably also restricted by its position within the larger business. Financial theory suggests that a diversified corporation undergoes a 'conglomerate discount' in the stock market that makes acquisitions more expensive, which is one of the reasons for Mannesmann's relatively low capital market valuation compared to Vodafone.

The Mannesmann case shows that spin-offs and return to corporate specialization can be undertaken with a consensus between shareholders, management, and labor. In sharp contrast to the conventional wisdom, capital market orientation and codetermination via 'co-management' are hardly irreconcilable opposites. Both groups share common interests in promoting competitiveness and managerial accountability, even if their class interests may conflict in other areas such as wages. Class conflicts have lost some of their sharpness since the mid-1990s relative to employee concern over questions of risk management, transparency, business strategies, and perverse incentives given to management. In these areas, the differences between investors and employees are not diametrically opposed. Instead, each actor may prefer different approaches to reach similar goals.

Labor representatives were justifiably afraid of job losses following a successful takeover and resulting reorganization. As a result, the works council and union cooperated to prevent the takeover. Notably, the friendly or hostile nature of the takeover did not play a central role in their argumentation. Instead, labor stressed their demands 
regarding business and corporate strategy: the integrated telecommunications strategy (fixed-line networks, mobile networks, Internet) should remain intact, the planned strategy for Mannesmann Röhrenwerke should also remain intact, and the planned IPO of the engineering and automotive businesses should go ahead. In mid-November, some 500 white-collar employees took part in a warning strike by leaving their offices five minutes before noon to demonstrate against the hostile bid. At the same time, the works councils held a press conference. The union and works councils were successful in involving telecommunications workers equally in the protest activities alongside employees from the industrial businesses. IG Metall boss Klaus Zwickel, a member of the Supervisory Board at Mannesmann, repeatedly voiced his position on the takeover: Mannesmann is a healthy company with excellent prospects and has a superior strategy to Vodafone. But astonishingly few conflictual reactions came from labor, in sharp contrast to the mass demonstrations and emotions during the 1997 takeover attempt of Thyssen by Krupp. Rather, works councils and trade unions supported the shareholder-centered defensive strategy chosen by Esser.

Up until February 2000, employee owners held up to an estimated $7.5 \%$ of share capital. Opponents of the takeover sought to mobilize the loyalty of this block to refuse the offer. Employee shareholders have an ambivalent function in such battles. On the one hand, employee stock ownership plans (ESOPs) are often given by shareholder valueoriented corporations to focus their employees on profitability targets. On the other hand, employees are strategic owners with long-term interests in the corporation beyond the maximization of shareholder returns. The employee stake at Mannesmann therefore does not automatically translate into a unified $7.5 \%$ block of votes against the takeover, particularly since employees at Mannesmann held shares individually rather than in trusteeship. In addition, employees had already sold many of their stocks, thereby reducing the total to far below $7.5 \%$. Thus, the representation of employee-owned shares at the shareholders' meeting is not usually very high. Following the Mannesmann takeover, some companies have attempted to organize employee owners into associations to bundle votes and assure representation. Lacking any such organization, the Mannesmann works council appealed to employees not to sell their shares. But at the end of November, the magazine Wirtschaftswoche reported the dramatic share prices appreciation had led many employee owners to sell their shares.

The sensational announcement by the American AFL-CIO that $13 \%$ of Mannesmann was held by funds in union control was ultimately ineffective too. According to William Patterson, Director of the Office of Investment, "This decision is not just about the takeover, but about a basic principle. It involves the question of whether the AngloAmerican or European model creates more value for investors over the long-term. We believe that the European model, which seeks consensus between employees and employers, is the more successful' (Handelsblatt, November 24, 1999). By late November, it had become clear that only $1-2 \%$ of shares were under the direct control of the AFL-CIO. Union President John Sweeney sent an eight-page letter to some 50 US investment managers holding
Mannesmann stakes, appealing to them to refuse the takeover bid. 'The managers of the employees' capital have a responsibility to invest in funds that promote the interests of investors in the long-term,' wrote Sweeney (emphasis added). However, the AFL-CIO is unlikely to influence funds outside its direct management. This union involvement did spark an intensive discussion among German unions about using pension funds and employee stock ownership to promote employee-oriented corporate governance. In February 2000, the chairman of the union federation, Deutsche Gewerkschaftsbund (DGB), Dieter Schulte proclaimed it a bold notion that the DGB could make up some of its lost influence over corporations through share ownership. German unions are anticipating the move toward a greater role for pension funds in the social security system and arguing that labor should have a voice in the resulting investment decisions.

'Germany - where capitalism operates a little differently': economic culture in politics, press, and public

The above headline from The Guardian (November 23, 1999) symbolizes the public ambivalence over the Vodafone bid. Was Mannesmann engaging in legitimate attempt to defend German institutions or would this constitute a nationalistic reaction to an inevitable development of global finance? In fact, the 'national card' was not invoked to fight off Vodafone. Representatives of the Social Democratic (SPD) Government and the Christian Democratic (CDU) opposition openly opposed the takeover in Mannesmann's home state of North Rhine-Westphalia. Chancellor Gerhard Schröder (SPD) likewise warned that hostile takeovers might threaten well-established corporate culture. Nonetheless, politicians did not actively intervene in the deal, and public debate was dominated by sober discussion and a remarkably shareholder-oriented perspective on the whole.

Given that an open political conflict was avoided, Mannesmann and Vodafone engaged advertising companies in an unprecedented public campaign. The total costs of the takeover defense were estimated to be 432 million euros, including 56 million for advertisements, 155 million for investment banks, 75 million for lawyers, and 146 million for other consultants. Meanwhile, Vodafone spent some three times this amount for advertising. Mannesmann's agencies such as KNNSK/BBDO in Hamburg were hired to counter Vodafone's ads and vice versa. Thus, a bizarre exchange of ads began, often with the ads displayed opposite one another, in which the companies themselves were the goods being sold. Shareholder activists are appalled at the high sums spent in the name of the shareholders' interests, and in December 1999 a lawsuit was filed to halt the spending but was refused by the higher court in Düsseldorf.

\section{The outcome}

By mid-January 2000, it had become increasingly clear that the majority of Mannesmann shareholders would sell to Vodafone. Foreign shareholders seemed clearly in favor of Vodafone, and held a majority of shares. Among domestic shareholders, opinion was estimated as being split 50:50. The takeover battle was decided when Klaus Esser's final and most spectacular defensive strategy failed: the search 
for a white knight. In the second week of January, rumors emerged that the French conglomerate Vivendi might become a partner in the takeover defense. Mannesmann surprisingly announced that Vivendi was its strongest partner and shared the same strategic vision. Amid merger rumors, Mannesmann announced it was developing plans for a merger of its core businesses with the telecommunications division of Vivendi. At the same time, Esser announced that a merger with Vodafone was being considered if Mannesmann shares made up a clear majority in the new company, with $58.5 \%$ being given as a realistic figure. Chris Gent had offered Mannesmann shareholders only a $48.9 \%$ share of the new company. By the end of January, Vodafone entered into negotiations with Vivendi and sought to win them as a possible buyer of Orange following the takeover battle. The fronts shifted, as Vivendi announced a joint Internet portal with Vodafone if the takeover succeeded. The white knight strategy had failed.

At this point, the blockholder, Hutchinson Whampoa, intervened to press Esser to accept the Vodafone offer. On February 3, 2000, an agreement was announced between Vodafone and Mannesmann. Klaus Esser accepted an improved bid giving Vodafone a $50.5 \%$ and Mannesmann a $49.5 \%$ share in the merged company. In addition, the agreement made a number of promises regarding the continuation of the integrated telecommunications strategy at Mannesmann, and all fixed-line network and Internet activities were to be moved to Düsseldorf. Assurances were given that Mannesmann subsidiaries Arcor and Infostrada would not be sold and that the IPO of the Atecs engineering and automotive businesses would proceed as planned in Summer 2000 without the divisions being broken up and sold as subunits. The Supervisory Board approved the plan on February 4 with the consent of the labor representatives. Klaus Zwickel (IG-Metall) expressed his satisfaction with the agreement: 'The employee representatives on the Supervisory Board accept the merger on this basis.' The merger agreement largely laid to rest fears of largescale dismissals, despite the fact that no formal guarantee was made. Shareholders had gained some 100 million euros, constituting a $120 \%$ rise in the share price between midOctober 1999 and February 3, 2000. Thus, shareholders were able to realize gains through the takeover battle as a result of the increased offer to Mannesmann shareholders.

In the end, not all of Vodafone's promises were kept. Vodafone generated over 14 billion euros selling off various divisions of Mannesmann - including Orange to France Telecom as well as the traditional tubes business to Salzgitter for 1 euro. Notably, Atecs was sold to Siemens $A G$ and Robert Bosch $\mathrm{GmbH}$ rather than undergoing the promised IPO. Ironically, Vodafone has retained the fixed line telephone business Arcor as part of the group. Compared to the 14,778 telecommunications workers at Mannesmann in 1998, Vodafone employed 10,124 people in Germany during 2006 through these subsidiary firms.

The takeover battle was followed by a quarrel over Esser's compensation upon loosing his office, known in the US as a 'golden handshake.' At the urging of Canning Fok from Hutchinson Whampoa, Esser received about 30 million euros as he was removed from his position as CEO (although this includes some variable pay that he would have gained anyway because of the enormous share price increases). In September of 2003, the District Court of Düsseldorf put Esser and the responsible supervisory board committee members, including board members of Deutsche Bank, on trial for breach of fiduciary duty. In July 2004, the court found the accused not guilty. The trial was widely considered a test case for the acceptance of Anglo-American style executive compensation in Germany, but despite the clearly negative view of the courts, failed to come up with a decisive criteria for the 'appropriateness' of executive compensation. ${ }^{3}$ However, the District Court announced a new legal review of the case starting in July 2006.

\section{An emerging market for corporate control?}

The case of Mannesmann suggests that the institutional barriers to hostile takeovers (Section 3 ) proved to be absent or insufficient. It has been argued that Mannesmann case should not be interpreted as signifying the emergence of a market for corporate control in Germany (Heinze, 2001, 2004). Two empirical points are relevant here. First, compared to other countries, many institutional barriers to hostile takeovers in Germany appear quite stable ownership concentration remains high, bank-firm relationships persist, codetermination is stable, and legal changes fall short of imposing the strict board neutrality found under UK takeover rules. Second, the number of hostile deals in Germany has not yet converged to similar levels as countries such as Britain or the US.

In our view, these arguments overlook the significance of interrelated and incremental, but nevertheless transformative changes in institutions, actors' strategies, and predominant business ideologies. In this section, we argue that a more actor-centered interpretation of institutional constraints suggests that the complementary nature of recent changes has indeed led to growing competition for corporate control. Moreover, cross-national convergence is an inappropriate benchmark to assess the emergence of a market for corporate control. Rather, markets may have a variety of shapes and sizes.

\section{Actor strategies regarding the Mannesmann takeover}

Which changes ultimately made the Mannesmann takeover possible? Legal changes played a role, particularly the one share-one vote rule introduced in 1998. However, what strikes us is that the most obvious precondition of a market for corporate control - codified takeover regulation that effectively limits the managers' room for maneuver concerning defensive measures - plays no direct role in explaining the Mannesmann case. In late 1999, German takeover rules were much less bidder-friendly than today following the German law and European Takeover Directive. This finding, we argue, has interesting implications for business research and political economy. First, not takeover regulation, but interrelated changes of institutions, business practices, and ideologies - the factors in which M\&A are socially embedded - provide explanatory power. Secondly, changes in the way actors use institutions are at least as important as changes in formal or legal institutions. 
Mannesmann's vulnerability depended on the high fragmentation of ownership among institutional and foreign investors. While untypical among German companies as a whole, this pattern is common among listed blue chips. Despite the 'small world' structure of the German corporate network (see Kogut and Walker, 2001), strategic owners such as German banks are increasingly unlikely to provide takeover protection and use their central position to influence M\&A activity itself. The Deutsche Bank's attempt to develop its reputation as investment banker preempted any active defensive role at Mannesmann. For the very same reason, banks are selling off their shares of industrial companies and eroding the degree of protection within the German company network. Between 1996 and 2004, the number of capital ties between the 100 largest companies decreased from 168 to 44 (data: Monopolkommission.). Codetermination also failed to have its expected deterrent effect at Mannesmann. Vodafone rightly speculated that the consensus and productivity oriented form of codetermination in large German companies today no longer acts as a 'poison pill' for hostile bids. This view was reinforced by the public adjustment to 'shareholder culture,' such that hostile takeovers no longer appear unthinkable for domestic business practices anymore.

Given weak resistance from key stakeholders, regulatory factors discussed earlier (accounting rules, corporate law, competition law, and other defensive actions) were insufficient to ward off a hostile bid or construct an adequate defense. Mannesmann's use of German accounting rules did not discourage the bid. Likewise, past voting rights caps in the Mannesmann corporate statutes were voided by legal reforms in 1998. One legal issue was whether the sale of Orange would require a 'control contract' through a super-majority vote - an issue later criticized by shareholder activists, who felt the sale of Orange was not in the interests of Mannesmann. However, the very strong M\&A market in European telecommunications left little doubt that Orange could quickly be sold at a high price. In the end, the main defensive action taken by Mannesmann management was the search for a white knight. White knight strategies are always uncertain, and the failure to secure an agreement with Vivendi certainly sealed the outcome of the takeover battle.

Mannesmann also exemplifies the substantial moves already made toward a corporate culture of 'shareholder value.' The spin-off of traditional businesses was already planned before the takeover and was no longer an issue in the takeover battle. Although the two competing management teams did propose substantially different corporate strategies, they reflect a similar argumentation in terms of shareholder value. As Esser explained at the final posttakeover shareholders meeting of the Mannesmann AG:

Why did we resist the takeover bid? It was because the offer to pay 263 Euro was wrong. The purpose of the takeover battle was for the shareholders to get the 350 Euro which they received... Ladies and Gentlemen, what happened here was pure shareholder democracy. The majority decided. An extraordinary shareholders' meeting would not have helped this decision. Shareholder democracy takes place in the stock market.
These changes in ideology have been reinforced by changes in managerial careers toward greater focus on finance. For example, between 1990 and 1999, the share of financial experts among the CEOs of the 40 largest companies rose from less than 25 to over $30 \%$. All forty of these managers had university degrees. More dramatically, the share of CEOs recruited from outside the companies doubled from 17 to more than $35 \%$ and the average time in office of CEOs halved from around 13 years in 1965 to less than 7 years in 1996 (see Höpner, 2001: 2124). Clearly, managers of German companies are developing stronger financial expertise and no longer spend their whole career in one company. Therefore, we argue that the ideological shift towards greater financial and investor orientation is likely to persist.

In sum, we see the emergence of a market for corporate control as being the result of interrelated changes in ideologies, business practices, legal rules, and the strategic use of institutions. Theoretically, this argument suggests the importance of strategic and institutional complementarities in a dynamic sense (Aoki, 2005). The Momentum Theorem (Milgrom et al., 1991) suggests that even if the initial level of competence conducive to an institution $\mathrm{X}$ is low, the presence of complementary institutions in other domains may amplify the impact of a policy intended to induce $X$, and that once a momentum is initiated, $X$ may gradually evolve as a viable institution. Complementarities among specific institutions are thereby historically constituted and variable as actors develop new competencies and learn to use institutions in new ways (Morgan and Kubo, 2005).

Our case study shows existing institutional structures in Germany do not preclude strategies of hostile takeovers, but that their emergence has depended upon the gradual accumulation of competencies in using the stock market, particularly among top managers, which make the 'marketization' of corporate control possible. This suggests maybe surprisingly - that the function of takeover regulation is linked to the changing use of institutions such as codetermination. We conclude that to understand 'markets' such as the takeover market, it is necessary to examine the broader configuration of the business system in an actor-centered manner. Changing strategies may be possible without a collapse in the structure of national capitalisms.

\section{Mannesmann in context: other hostile bids}

Hostile deals are not entirely new to Germany prior to Mannesmann. Despite the absence of other large public offers, hostile changes of control are sometimes triggered by the breakup of an existing coalition among several large blockholders. ${ }^{4}$ Looking at the period of 1995-2005, we have compiled a list of all hostile takeover attempts of German target firms. ${ }^{5}$ The list combines six cases classified by the Thomson Banker One 'Deals' database as being hostile transactions, but also reflects an electronic search of German language newspapers to identify other hostile cases, particularly examples of hostile stakebuilding.

We identify 15 cases involving German target firms where hostile bids were made or control was contested by unsolicited offers or the building of hostile stakes. While 
only two cases were observed between 1995 and 1999, 13 cases were observed between 2000 and 2005. Most have targeted mid-cap firms in either high growth or consolidating sectors. Nine out of 15 cases resulted in the sale of the target firm to the raider. However, the takeovers of Mannesmann and Kamp AG were the only cases where bidders succeeded in an open market hostile bid. Other cases involved hostile stakes that were used to 'leverage' the hostile transaction by breaking down management resistance. For example, WCM held a $39.3 \%$ stake in Kloeckner before launching its hostile offer. INA KG likewise accumulated a $30 \%$ minority stake in FAG Kugelfischer before its bid was successful. These cases reflect changes in the orientation of large strategic stakeholders, and the growing legitimacy to exert market pressure on strategic partners.

In the other six cases, the hostile bidder failed. Two of these involved white knights or alternative bidders. ${ }^{6}$ Steel producer Salzgitter Stahl was able to fend off the Austrian acquirer Voest Alpine in 1998 as the state government of lower Saxony and the regional bank, Norddeutsche Landesbank, purchased friendly stakes to ward off the acquisition. In 2004, as the Dutch owner ING sold its large stake in BHF Bank, BHF managers also warded off a deal with Commerzbank in favour of a deal with Sal Oppenheim. In the remaining four cases, the target firm remained independent. Deutsche Balaton AG failed in its bid for Beta Systems in 2002, largely due to resistance of the company founders who retained a $25 \%$ minority stake. In 2003, Eurocom failed in its bid for Winter AG following intervention by the stock exchange regulators regarding false information given by the acquirer. In 2004, a management buy-out failed whereby SMS would have taken over its parent company, MAN AG but failed due to resistance of large shareholders such as Allianz, Commerzbank and Muechener Rueckversicherung. In 2002, the Austrian Lasselsberger Group announced a hostile bid for Deutsche Steinzeug, but withdrew the offer once Deutsche Steinzeug agreed to sell a $95 \%$ stake of Czech Rako SA to the Lasselsberger Group.

Surely, the 15 attempted hostile takeovers in Germany remains small compared to the $\mathrm{UK}$, which has averaged roughly 11 hostile bids per year between 1991 and 2005 . Likewise, these figures are far below the 40-50 bids per year at the beginning of the 1980s wave of hostile takeovers in the US. The 'openness' of the German takeover market has not converged to that of Anglo-Saxon countries. M\&A transactions are still structured by Germany's more 'coordinated' business institutions - for example, German firms make more use of stake acquisitions than complete mergers, bidders have high levels of prior ownership in target firms, and deals rely on greater use of private negotiation and large block purchases (Kogut and Walker, 2001; Jackson and Miyajima, 2006). Open market hostile bids, such as Mannesmann, remain highly exceptional. Nonetheless, despite continued institutional barriers to takeovers, the strategies of key actors have changed substantially in ways that make the threat of hostile transactions in Germany real. What constitutes a 'market' (for corporate control) is, in fact, the intensified competition over the control of large companies, and competitive strategies oriented to stock prices to mediate that competition. This marketization is reflected in the general growth of M\&A transactions and high likelihood of poorly performing firms to be taken over.

\section{Institutional change and corporate governance}

In this article, we have used a detailed analysis of a single event in order to understand a process of institutional change (see also Baker, 1992). This change results from an altered use of pre-existing institutions, rather than from legal reform or disappearance of past institutional structures. While legal rules and other institutional structures are important parts of the story, our case study points to two shortcomings of existing institutional analysis of the market for corporate control. First, institutions, such as legal protection of investors and takeover regulation, should not be looked at in isolation. By contrast, we have argued that incremental but complementary changes in related institutions and practices that appear far away from M\&A activity - such as codetermination - matter decisively. Such changes can cumulate into the emergence of a 'market' in the sense of greater competition over corporate control based around stock prices. Second, our analysis underlies the necessity of an actor-centered perspective that takes into the account the fact that particular institutions may be put to an enormous variety of possible uses. In addition to comparing institutions structures across countries, a deeper look at the social embeddedness of markets is necessary to understand the creeping, if yet not entirely finished, emergence of a market for corporate control in Germany.

Our findings also underline the importance of events as markers of institutional change. The actual functioning of institutions is always uncertain and leaves scope for reinterpretation and different uses (Streeck and Thelen, 2005). However, if the significance of complementarity for the emergence of a market for corporate control is correct, the functioning of institutions is even more difficult to predict and requires periodic experimentation. Before the takeover battle between Vodafone and Mannesmann, none of the actors involved actually knew how managers, works councils, trade unions, politics, and the general public would behave. Uncertainty existed as to whether the German economic culture had actually changed so much that a hostile takeover of one of the largest German companies by a foreigner would be possible. In this respect, the significance of Mannesmann does not lie in the change directly caused by the event. Rather, events are required by actors to reveal the state of development of an economic culture - which reflects the whole set of institutions, ideologies, and practices related to the legitimacy of certain economic behavior. The Mannesmann case has revealed that the traditional view on German capitalism does not hold anymore. A hybrid has emerged that consists the institutions of both the 'social market economy,' such as codetermination, as well as the possibility of hostile takeovers, which is usually seen as being incompatible with a stakeholder economy.

Our analysis has focused on the reasons for emergence of a market for corporate control rather than on its likely consequences. We admit that the long-term implications are still an open question. However, we argue that takeover 
markets alter the incentives and constraints for major actors as well as firms in the direction of greater shareholder orientation. In light of the distributional consequences of different corporate governance systems, we speculate that - for good or bad - the typical German strategy based on comparatively low profit margins, low share prices and high preference for company growth and employment (Höpner and Jackson, 2001: 12-17) is likely to slowly adjust to the Anglo-Saxon focus on higher return on equity to sustain higher share valuations - in part, to reduce vulnerability to potential hostile bids. Also, we doubt that the small company sector will remain unaffected by the changes we analyzed in the paper. Companies directly affected by the market for corporate control are the largest of the large. However, due to their strong position vis-à-vis smaller companies, these companies have room for passing a part of their profitability pressures towards smaller suppliers and customers. Consequently, it is even possible that the German Mittelstand sector will turn out to be the main loser of current developments. The future will reveal whether these possible negative consequences will be outweighed by efficiency and investment in emerging sectors due to higher profitability.

\section{Acknowledgements}

We thank Jürgen Beyer, Jürgen Donges, Ronald Dore, Werner Eichhorst, Roland Köstler, Colin Mayer, Bruce Kogut, Anke Hassel, and two anonymous reviewers for comments on an earlier draft. In particular, we thank members of the Mannesmann management and works council, as well as IG Metall for their cooperation with interviews and providing documents. Marc Rufo provided excellent research assistance. Any errors are our own.

\section{Notes}

1 During 1998-2005, the value of domestic deals was $1.9 \%$ of GDP compared to $2.4 \%$ of GDP for German firms acquiring foreign targets or $3.4 \%$ of GDP for foreign firms acquiring German targets.

2 Confidential interviews suggest that Vodafone actually considered the hostile takeover bid in early 1999. At this time, the Vodafone management did not know that the parity model of codetermination would be removed later in 1999, suggesting that even the strongest form of codetermination is not seen as a de facto poison pill.

3 For a discussion of the legal implications, see Maier (2006) and Kolla (2004).

4 Jenkinson and Ljungvist (2001) identified 14 successful cases out of 17 cases hostile stake-building between 1988 and 1996.

5 Not included here are several important examples of hostile bids made by German firms for foreign targets. For example, the Deutsche Börse made a hostile offer for the London Stock Exchange in January 2005, the failure of which eventually resulted in the removal of the CEO and supervisory board chairman at Deutsche Börse.

6 A further important case emerged in the German pharmaceuticals industry during March 2006 was the white knight acquisition of Schering AG by Bayer AG following a hostile bid from Merck KGaA.

\section{References}

Aguilera, Ruth V. and Gregory Jackson, 2003, "The cross-national diversity of corporate governance: dimensions and determinants". Academy of Management Review, 28: 447-465.

Aguilera, Ruth V. and John C. Dencker, 2004, "The role of human resource management in cross-border mergers and acquisitions". International Journal of Human Resource Management, 15(8): 1355-1370.

Aoki, Masahiko, 2005, Schumpeterian innovation of institutions. Unpublished paper, Research Institute of Economy, Trade and Industry, Tokyo.

Baker, George P., 1992, "Beatrice: A study in the creation and destruction of value". Journal of Finance, 47(3): 1081-1119.

Baums, Theodor, 1993, "Takeovers versus institutions in corporate governance in Germany". In Daniel D. Prentice and Peter R.J. Holland (eds.) Contemporary issues in corporate governance. Oxford: Clarendon Press, pp: 151-183.

Buck, Trevor W. and Azura Shahrim, 2005, "The translation of corporate governance changes across national cultures: The case of Germany". Journal of International Business Studies, 36: 42-61.

Bundesministerium, der Finanzen, 2000, "Entwurf eines Gesetzes zur Regelung von Unternehmensübernahmen". http://www.bundesfinanzministerium.de.

Callaghan, Helen and Martin Höpner, 2005, "European integration and the clash of capitalisms. Political cleavages over takeover liberalization". Comparative European Politics, 3: 307-332.

Conyon, Martin J., Sourafel Girma, Steve Thompson and Peter Wright, 2001, "Do hostile mergers destroy jobs?" Journal of Economic Behavior o Organization, 45: 427-440.

Conyon, Martin J, Sourafel Girma, Steve Thompson and Peter Wright, 2004, "Do wages rise of fall following a merger?" Oxford Bulletin of Economics and Statistics, 66: 847-862.

Crouch, Colin, 2005, Capitalist diversity and change. Recombinant governance and institutional entrepreneurs. Oxford: Oxford University Press.

De Jong, Henk W., 1996, "European Capitalism Between Freedom and Social Justice". In Bratton William, McCahery Joeseph, Picciotto Sol and Scott Colin (eds.) International Regulatory Competition and Coordination: Perspectives on Economic Regulation in Europe and the United States. Oxford: Clarendon Press, pp: 185-206.

Deminor Rating, 2005, Application of the one share-one vote principle in Europe. Brussels: Deminor Rating.

Deutsche Bank, 2001, Die Corporate Governance-Grundsätze der Deutschen Bank. Corporate Governance als Teil des Selbstversändnisses der Deutschen Bank. Frankfurt am Main: Deutsche Bank AG.

Fiss, Peer C. and Edward Zajac, 2004, "The diffusion of ideas over contested terrain: The (non)adoption of a shareholder value orientation among German firms". Administrative Science Quarterly, 46: 202-228.

Fligstein, Neil, 1990, The transformation of corporate control. Cambridge, MA: Harvard University Press.

Franks, Julian and Colin Mayer, 2001, "The ownership and control of German corporations". Review of Financial Studies, 14: 943-977.

Goergen, Marc, Marina Martynova and Luc Renneboog, 2005, Corporate governance convergence: Evidence from takeover regulation reforms in Europe. Discussion Paper Series 05-19. Utrecht School of Economics, Utrecht.

Gordon, Jeffrey N., 2003, An American perspective on anti-takeover laws in the EU: The German example. Working Paper. Columbia Law School, Center for Law and Economic Studies.

Guillén, Mauro F., 1994, Models of management. Work, authority and organization in comparative perspective. Chicago, IL: University of Chicago Press.

Hackethal, Andreas, Reinhard H. Schmidt and Marcel Tyrell, 2005, "Banks and German corporate governance: On the way to a capital-market based system?" Corporate Governance: An International Review, 13: 397-407. Hall, Peter A, and David Soskice, 2001, Varieties of capitalism: The institutional foundations of comparative advantage. Oxford: Oxford University Press.

Heinze, Thomas, 2001, "Transformation des deutschen UnternehmenskontrollSystems? Eine empirische Analyse zum Stellenwert der feindlichen Übernahme der Mannesmann AG für die Unternehmenskontroll-Debatte". Kölner Zeitschrift für Soziologie und Sozialpsychologie, 53: 641-675.

Heinze, Thomas, 2004, "Dynamics in the German system of corporate governance? Empirical findings regarding interlocking directorates". Economy and Society, 33: 218-238. 
Höpner, Martin, 2001, Corporate governance in transition: Ten empirical findings on shareholder value and industrial relations in Germany. Discussion Paper 01/5, Max Planck Institute for the Study of Societies, Cologne.

Höpner, Martin, 2003, Wer beherrscht die Unternehmen? Shareholder Value, Managerherrschaft und Mitbestimmung in großen deutschen Unternehmen. Frankfurt am Main: Campus.

Höpner, Martin and Gregory Jackson, 2001, "An emerging market for corporate control? The Mannesmann takeover and German corporate governance". Discussion Paper 01/4, Max Planck Institute for the Study of Societies, Cologne.

Höpner, Martin and Lothar Krempel, 2004, "The politics of the German company network". Competition and Change, 8: 339-346.

Jackson, Gregory, 2003, "Corporate governance in Germany and Japan: Liberalization pressures and responses". In K.Yamamura and W. Streeck (eds.) The end of diversity? Prospects for German and Japanese capitalism. Ithaca, NY: Cornell University Press, pp: 261-305.

Jackson, Gregory and Hideaki Miyajima, 2006, Varieties of takeover markets: Comparing mergers and acquisitions in Japan with Europe and the USA. Discussion Paper, Research Institute of Economy, Trade and Industry, Tokyo (forthcoming).

Jenkinson, Tim and Alexander Ljungvist, 2001, "The role of hostile stakes in German corporate governance". Journal of Corporate Finance, 7: $397-446$.

Kester, W.Carl, 1990, Japanese takeovers: The global contest for corporate control. Boston, MA: Harvard Business School Press.

Kogut, Bruce and Gordon Walker, 2001, "The small world of Germany and the durability of national networks". American Sociological Review, 66: 317-335.

Kolla, Peter, 2004, "The Mannesmann trial and the role of the courts". German Law Journal, 5(7): 829-847.

La Porta, Rafael, Florencio Lopez-de-Silanes, Andrei Schleifer and Robert W. Vishney, 1998, "Law and finance". Journal of Political Economy, 106: 1113-1155.

Maier, Stefan, 2006, "A close look at the Mannesmann trial". German Law Journal, 7(6): 603-610.

Manne, Henry, 1965, "Mergers and the market for corporate control". Journal of Political Economy, 73: 110-120.

Martynova, Marina and Luc Renneboog, 2006, Mergers and acquisitions in Europe. Working Paper No. 114. European Corporate Governance Institute, Brussels.
Milgrom, Paul R., Y. Qian and John Roberts, 1991, "Complementarities, momentum, and the evolution of modern manufacturing". American Economic Review, 81: 84-88.

Morgan, Glenn and Izumi Kubo, 2005, "Beyond path dependency? Constructing new models for institutional change: The case of capital markets in Japan". Socio-Economic Review, 3: 55-82.

O'Sullivan, Mary, 2000, Contests for corporate control: Corporate governance and economic performance in the United States and Germany. Oxford: Oxford University Press.

Pagano, Marco and Paolo Volpin, 2005, "The political economy of corporate governance". American Economic Review, 95: 1005-1030.

Poensgen, Otto H., 1982, "Der Weg in den Vorstand. Die Charakteristiken der Vorstandsmitglieder der Aktiengesellschaften des verarbeitenden Gewerbes". Die Betriebswirtschaft, 42: 3-25.

Rossi, Stefano and Paolo Volpin, 2003, Cross-country determinants of mergers and acquisitions. Finance Working Paper No. 25, European Corporate Governance Institute, Brussels.

Sako, Mari and Gregory Jackson, 2006, "Strategy meets institutions: The transformation of management-labor relations at Deutsche Telekom and NTT". Industrial and Labor Relations Review, 59: 347-366.

Sanders, W.M.Gerard and Anja Christine Tuschke, 2007, "The adoption of institutionally contested organizational practices: The emergence of stock option pay in Germany". Academy of Management Journal (forthcoming).

Schmidt, Hartmut, 1997, Corporate governance in Germany. Baden-Baden: Nomos.

Schneper, William D. and Mauro F. Guillen, 2004, "Stakeholders rights and corporate governance: A cross-national study of hostile takeovers". Administrative Science Quarterly, 49: 263-295.

Shleifer, Andrei and Lawrence H. Summers, 1988, "Breach of trust in hostile takeovers". In Auerbach, Alan J. (ed.) Corporate takeovers: Causes and consequences. Chicago, IL: The University of Chicago Press, pp: 33-68.

Spieker, Wolfgang and Heinrich Strohauer, 1982, 30 Jahre Management gegen die Montan-Mitbestimmung. Tatsachen und Deutungen des Konflikts Mannesmann/IG Metall 1980/81. Köln: Bund Verlag.

Streeck, Wolfgang and Kathleen Thelen, 2005, Beyond continuity: Explorations in the dynamics of advanced political economies. Oxford: Oxford University Press.

Vitols, Sigurt, 2004, "Negotiated shareholder value: The German version of an Anglo-American practice". Competition and Change, 8: 1-18.

Windolf, Paul, 1994, "Die neuen Eigentümer. Eine Analyse des Marktes für Unternehmenskontrolle". Zeitschrift für Soziologie, 23: 79-92. 